\title{
Biokaasuketjun ravinne- ja energiataseet sekä ilmastovaikutukset
}

\author{
Elina Tampio $^{1)}$, Taija Sinkko ${ }^{2)}$, Karetta Timonen ${ }^{2)}$, Sanna Marttinen ${ }^{3)}$, Sari Luostarinen ${ }^{2)}$, Juha Grön- \\ $\operatorname{roos}^{4)}$ ja Kaisa Manninen ${ }^{4)}$ \\ ${ }^{1)}$ Luonnonvarakeskus (Luke), Tietotie 2c, 31600 Jokioinen, etunimi.sukunimi@luke.fi \\ ${ }^{2)}$ Luonnonvarakeskus (Luke), Latokartanonkaari 9, 00790 Helsinki, etunimi.sukunimi@luke.fi \\ ${ }^{3)}$ Luonnonvarakeskus (Luke), Viikinkaari 4,00790 Helsinki, etunimi.sukunimi@luke.fi \\ ${ }^{4)}$ Suomen ympäristökeskus (SYKE), Mechelininkatu 34a, PL 140, 00251 Helsinki, etuni- \\ mi.sukunimi@ymparisto.fi
}

\section{Tiivistelmä}

Kansallisen ilmasto- ja energiastrategian mukaisesti Suomi tulee lisäämään maatalouspohjaisen biomassan energiakäyttöä hyödyntäen erityisesti muita kuin ruuaksi käytettäviä kasveja ja kasvinosia, sekä elintarviketuotannon sivujakeita ja jätteitä (ml. lanta). Yksi hyödyntämiskeino on biokaasuteknologia, jossa yhdistyvät uusiutuvan energian tuotannon ohella ravinteiden kierrätys, biojätteiden käsittely, jätehuolto sekä päästöjen hallinta. Vaikka biomassan hyödyntäminen energiakäyttöön tuottaakin mahdollisia päästövähennyksiä, on haitallisten ilmastovaikutusten minimoimiseksi kuitenkin tärkeää huomioida koko käsittelyketju raaka-aineiden hankinnasta lopputuotteiden käyttöön.

Tämän tutkimuksen tavoitteena oli tarkastella pääasiassa lantaa käsittelevien biokaasulaitoksien energia- ja ravinnetaseita sekä löytää ilmastonmuutoksen hillinnän näkökulmasta parhaat toimintatavat. Biokaasuketjut pyrittiin määrittelemään nykykäytäntöjä vastaaviksi perustuen aiempiin tutkimuksiin, kirjallisuustietoon sekä asiantuntija-arvioihin. Tarkasteltavaksi kokoluokaksi valittiin kapasiteetiltaan 19500 tonnia vuodessa käsittelevä laitos mikä vastaa Suomen mittakaavassa usean kotieläintilan lantoja käsittelevää biokaasulaitosta, jonka syötemateriaali koostui sian lietelannasta (16 000 tonnia/vuosi) ja lisäsyötteestä (3 500 tonnia/vuosi). Lisäsyöte oli joko sian lietelannasta erotettua kuivajaetta, HVP-nurmea (hoidettu viljelemätön pelto) tai elintarviketeollisuuden sivutuotetta. Tarkastellut biokaasuketjut sisälsivät myös syötemateriaalien hankinnan ja lopputuotteiden, kuten sähkön ja lämmön, käytön sekä lannoitteena käytettävän käsittelyjäännöksen sellaisenaan tai separoituna neste- ja kuivajakeeksi. Tarkastelussa verrattiin kolmea eri syöteseosta käyttävää biokaasuketjua referenssitilanteeseen, jossa syötemateriaalit eivät päädy biokaasuprosessiin.

Tarkastelussa havaittiin, että lisäsyötteen vaikutus käsittelyjäännöksen ominaisuuksiin oli vähäinen, koska lietelannan osuus oli syötteessä huomattavan suuri. Käsittelyjäännöksen separoinnissa typpi ja kalium päätyivät pääosin nestejakeeseen ja jopa $70 \%$ fosforista puolestaan kiintoaineeseen. Kaikki kolme biokaasuketjua tuottivat energiaa yli oman tarpeen, senkin jälkeen, kun huomioitiin laitoksen oma kulutus sekä materiaalien kuljetus ja peltolevitys. Ilmastovaikutukset kaikissa tarkastelluissa biokaasuketjuissa olivat pienemmät verrattuna referenssitilanteeseen, sillä tuotetulla biokaasulla korvattiin fossiilisia polttoaineita ja saatiin siten päästöhyvityksiä. Jonkin verran hyvityksiä saatiin myös mineraalilannoitteiden korvaamisesta kierrätysravinteilla, mutta tämä ei ollut kovin suuri ja hyvitys koski myös referenssiketjuja. Suurimmat ilmastohyödyt saatiin biokaasuketjusta, jonka raakaaineena käytettiin sian lietelantaa ja HVP-nurmea, sillä se tuotti eniten energiaa jolloin korvaushyöty vältetystä fossiilisesta energiasta (kivihiili) oli suurin. Korvattavan energiamuodon valinnalla onkin suuri merkitys ilmastovaikutustulokseen.

Referenssitilanteessa suurin osa kasvihuonekaasupäästöistä aiheutui lannan varastoinnista ja peltokäytöstä kun taas biokaasuketjujen suurin päästölähde oli käsittelyjäännöksen peltokäyttö, sillä oletuksena oli, että lanta kuljetetaan tuoreeltaan biokaasulaitokselle suljettuihin säiliöihin, jolloin vältetään lannan varastoinnista aiheutuvat päästöt. Lannan ohella myös käsittelyjäännöksen varastoinnin päästöt minimoitiin varastoimalla jäännös suljetuissa säiliöissä.

\section{Asiasanat}

biokaasulaitos, ravinteet, ilmastonmuutos, käsittelyjäännös, lietelanta, HVP-nurmi, elintarviketeollisuuden sivutuotteet, energiatase 


\section{Johdanto}

Kansallisen ilmasto- ja energiastrategian mukaisesti Suomi tulee lisäämään maatalouspohjaisen biomassan energiakäyttöä hyödyntäen erityisesti muita kuin ruuaksi käytettäviä kasveja ja kasvinosia, sekä elintarviketuotannon sivujakeita ja jätteitä (ml. lanta). Yksi hyödyntämiskeino on biokaasuteknologia, jossa yhdistyvät uusiutuvan energian tuotannon ohella ravinteiden kierrätys, biojätteiden käsittely, jätehuolto sekä päästöjen hallinta. Vaikka biomassan hyödyntäminen energiakäyttöön tuottaakin mahdollisia päästövähennyksiä, on ilmastovaikutusten minimoimiseksi tärkeää huomioida koko käsittelyketju raaka-aineiden hankinnasta lopputuotteiden käyttöön.

Tämän työn tavoitteena oli tarkastella pääasiassa lantaa käsittelevän biokaasulaitoksen kokonaisketjua raaka-aineista lopputuotteiden käyttöön ja tunnistaa ketjun energia- ja ravinnetaseiden sekä ilmastovaikutusten näkökulmasta parhaat toimintatavat. Tarkastelua varten valittiin kolme erilaista syöteseosta, joille laadittiin prosessointiketju. Lähtökohtana oli, että laitosten toteuttaminen olisi taloudellisesti realistista nykytilanteessa. Tämän takia esim. pelkkää lietelantaa käsittelevää biokaasulaitosta ei tarkasteltu, vaan lietelannan lisänä käytettiin joko lannasta separoitua kuivajaetta, hoidettujen viljelemättömien peltojen nurmea (HVP-nurmi) tai elintarviketeollisuuden sivutuotteita. Tarkasteltavaksi kokoluokaksi valittiin laitos, jonka käsittelykapasiteetti oli 19500 tonnia vuodessa. Tämä kokoluokka vastaa Suomen mittakaavassa usean eläintilan lantoja käsittelevää biokaasulaitosta. Työssä pyrittiin myös vertailemaan biokaasuprosessissa muodostuvan käsittelyjäännöksen ja sen separoinnissa muodostuneiden kuiva- ja nestejakeiden ravinne- ja energiataseita sekä ilmastovaikutuksia, huomioiden myös massojen kuljetus ja peltolevitys (kuva 1).

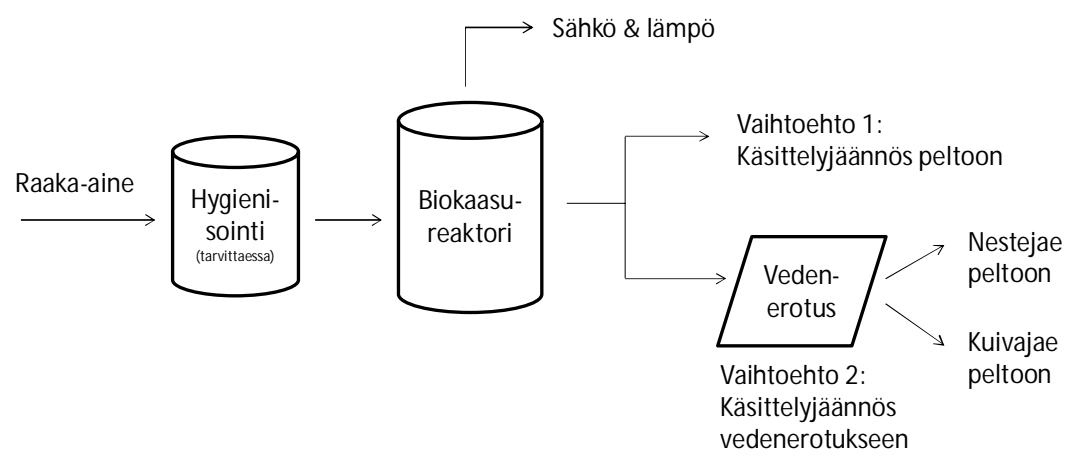

Kuva 1. Tarkasteltujen biokaasulaitosten kuvaus ja jäännöksen käsittelyvaihtoehdot.

\section{Aineisto ja menetelmät}

\section{Biokaasu- ja referenssiketjut}

Työssä tarkasteltiin kolmea erilaista biokaasulaitoksen syöteseosta ja niiden käsittelystä koostuvia biokaasuketjuja (BK1-BK3). Näiden lisäksi biokaasuketjuja verrattiin referenssiketjuihin (REF1REF3), jotka eivät sisällä biokaasulaitosta, vaan kuvaavat ko. syötteiden tyypillisiä käsittelyprosesseja nykytilanteessa (taulukko 1). Tarkempi kuvaus biokaasu- ja referenssiketjuista on esitetty julkaisussa Marttinen ym. (2015).

Kaikissa biokaasuketjuissa käsitellään lähtökohtaisesti 16000 tonnia vuodessa sian lietelantaa ja 3500 tonnia lisäsyötettä, mutta ketjun BK1 tapauksessa lietelannan määrä on kokonaisuudessaan lähes 37000 tonnia. Tämä johtuu siitä, että BK1 -ketjun lisäsyötteenä käytetyn kuivajakeen määrä (3 500 tonnia) tuotetaan separoimalla noin 21000 tonnia lietelantaa. Kaikissa tarkastelluissa biokaasuketjuissa lietelantaa varastoidaan vain lyhyt aika maatilalla, minkä jälkeen $16000 \mathrm{t}$ lietelantaa kuljetetaan biokaasulaitokselle $(10 \mathrm{~km})$, varastoidaan katetussa esisäiliössä ja pumpataan biokaasureaktoriin.

Lietelannan lisäksi biokaasureaktoriin lisätään 3500 t lisäsyötettä. Ketjussa BK1 osa lietelannasta eli 20792 tonnia separoidaan maatilalla, josta muodostuu lingottaessa 3500 tonnia kuivajaetta ja 17292 tonnia nestejaetta. Separoitu nestejae jää tiloille, jossa se varastoidaan katetussa säiliössä ja kuljetetaan $(5 \mathrm{~km})$ lannoitteena peltoon. Kuivajae kuljetetaan biokaasulaitokselle $(20 \mathrm{~km})$. Ketjussa BK2 HVP-nurmi (3 500 t) korjataan kerran vuodessa. Korjuun jälkeen nurmi lastataan ja kuljetetaan biokaasulaitokselle $(50 \mathrm{~km})$. Ketjussa BK3 elintarviketeollisuuden sivutuotteet (3 $500 \mathrm{t}$ ) varastoidaan lyhyen aikaa syntypaikalla katetussa säiliössä ennen kuljetusta biokaasulaitokselle (etäisyys $50 \mathrm{~km}$ ). Lisäsyötteet varastoidaan biokaasulaitoksella katetuissa varastoissa/säiliöissä ja siirretään biokaasure- 
aktoriin. Biokaasureaktorissa lannasta ja lisäsyötteistä muodostuva biokaasu johdetaan jälkikaasuuntumisaltaan yhteydessä olevaan kaasuvarastoon ja edelleen sähköä ja lämpöä tuottavaan CHPyksikköön. Prosessissa muodostuva käsittelyjäännös varastoidaan laitoksen jälkikaasualtaassa, joka toimii myös kaasuvarastona. Elintarviketeollisuuden sivutuotteet (BK3) hygienisoidaan ennen biokaasuprosessia (kuva 1).

Taulukko 1. Tarkastellut biokaasu- ja referenssiketjut sekä ketjujen syötemäärät.

\begin{tabular}{|l|l|l|}
\hline Tarkasteltava ketju & Lyhenne & Syötteet \\
\hline Biokaasuketju 1 & BK1 & $\begin{array}{l}\text { Sian lietelantaa 36 792 t/a } \\
\text { Lietelantaa biokaasulaitokseen } 16000 \mathrm{t} / \mathrm{a} \\
\text { Lietelantaa separaattoriin 20 792 t/a } \\
\text { Lietelannan nestejae peltolevitykseen } 17292 \mathrm{t} / \mathrm{a} \\
\text { Lietelannan kuivajae biokaasulaitokseen } 3500 \mathrm{t} / \mathrm{a}\end{array}$ \\
\hline Biokaasuketju 2 & BK2 & $\begin{array}{l}\text { Sian lietelanta } 16000 \mathrm{t} / \mathrm{a} \\
\text { HVP-nurmi } 3500 \mathrm{t} / \mathrm{a}\end{array}$ \\
\hline Biokaasuketju 3 & BK3 & $\begin{array}{l}\text { Sian lietelanta } 16000 \mathrm{t} / \mathrm{a} \\
\text { Elintarviketeollisuuden sivutuotteet 3500 t/a }\end{array}$ \\
\hline Referenssiketju 1 & REF1 & Sian lietelanta 36 792 t/a \\
\hline Referenssiketju 2 & REF2 & $\begin{array}{l}\text { Sian lietelanta } 16000 \mathrm{t} / \mathrm{a} \\
\text { HVP-nurmi 3 500 t/a }\end{array}$ \\
\hline Referenssiketju 3 & REF3 & $\begin{array}{l}\text { Sian lietelanta } 16000 \mathrm{t} / \mathrm{a} \\
\text { Elintarviketeollisuuden sivutuotteet 3500 t/a }\end{array}$ \\
\hline
\end{tabular}

Käsittelyjäännös hyödynnetään tiloilla lannoitteena joko sellaisenaan (vaihtoehto 1) tai separoituna neste- ja kuivajakeiksi (vaihtoehto 2) (kuva 1). Vaihtoehdossa 1 jäännös kuljetetaan takaisin tilalle (10 $\mathrm{km})$, jossa se ensin varastoidaan ja sitten kuljetetaan $(5 \mathrm{~km})$ ja levitetään peltoon. Vaihtoehdossa 2 jäännös separoidaan biokaasulaitoksella neste- ja kuivajakeeksi. Kuivajae kuljetetaan tiloille (10-20 $\mathrm{km})$, josta se varastoinnin jälkeen kuljetetaan ja levitetään peltoon $(5 \mathrm{~km})$. Nestejae kuljetetaan biokaasulaitokselta tiloille $(5 \mathrm{~km})$ ja varastoidaan ennen peltolevitystä.

Biokaasuketjujen ilmastovaikutusta verrattiin referenssiketjuihin vuositasolla. REF1 -ketjussa lietelantaa ei separoida kuivajakeeksi kuten BK1 -ketjussa, joten koko lantamäärää (36 792 t) tarkastellaan lietelantana sellaisenaan. Lietelanta varastoidaan maatiloilla lietesäiliöissä ja kuljetetaan pellolle levitettäväksi $(5 \mathrm{~km})$. Lietteestä 80 \% levitetään pääasiassa keväällä ja kesällä joko mullokselle tai oraille kylvön jälkeen. Mullokselle levitetty liete mullataan. Syksyllä liete (20\%) levitetään sängelle ja mullataan. REF2 -ketjun kuvaus on sian lietelannan osalta sama kuin REF1:ssä, mutta lietelannan määrä on 16000 t. HVP-nurmi (3 500 t) niitetään kerran vuodessa ja sato jätetään peltoon (n. 220 ha kun tuoresato 16 t/ha). HVP-nurmen tuotannossa lannoitus on vähäistä. Myös REF3 -ketjun kuvaus lietelannan osalta on sama kuin REF1:ssä, mutta lietelannan määrä on $16000 \mathrm{t}$. Elintarviketeollisuuden sivutuotteet ( $3500 \mathrm{t}$ ) varastoidaan tuotantolaitoksella, josta massat kuljetetaan kompostoitavaksi kompostointilaitokseen $(50 \mathrm{~km})$. Kompostointi tapahtuu aumassa, josta kompostoitunut massa lastataan ja kuljetetaan käytettäväksi viherrakentamisessa $(50 \mathrm{~km})$.

\section{Laskentaperusteet}

Biokaasu- ja referenssiketjuissa käytettyjen syötteiden ominaisuudet perustuvat kirjallisuusarvoihin sekä asiantuntija-arvioihin (taulukko 2), joihin pohjautuen laskettiin käsittelyketjujen ravinne- ja energiataseet sekä ilmastovaikutus. Referenssiketjuissa sianlannan ominaisuudet poikkesivat hieman biokaasuketjun lannan ominaisuuksista referenssilannan pidemmän varastoinnin ja sen aikaisten pitoisuusmuutosten vuoksi. Sian lietelannasta separoidun kuivajakeen ominaisuudet laskettiin lietelannan ominaisuuksien ja lannan separointilaitteiston erotustehokkuuksien perusteella. Sianlannan sekä biokaasulaitosten käsittelyjäännöksen separaattoriksi oletettiin sähkökäyttöinen linko, jonka erotustehot olivat kuivajakeelle seuraavat: massa $17 \%$, TS $67 \%$, VS $67 \%, \mathrm{~N}_{\text {kok }} 30 \%, \mathrm{NH}_{4}-\mathrm{N} 19 \%, \mathrm{P}_{\text {kok }} 74 \%$ (Hjorth ym. 2010) ja $\mathrm{K}_{\mathrm{kok}} 12 \%$. Separaattorin energiankulutukseksi oletettiin 2,5 kWh/t käsiteltävää materiaalia (Møller ym. 2000). Biokaasuprosessin aikana ravinteista vain liukoisen ammoniumtypen osuuden oletettiin muuttuvan, jolloin sekä kokonaistypen, -fosforin ja -kaliumin pitoisuudet pysyivät vakioina. Ammoniumtyppipitoisuuden nousuksi biokaasuprosessin aikana oletettiin sian lietelannalle ja sen kuivajakeelle $30 \%$ ja elintarviketeollisuuden sivutuotteille sekä HVP-nurmelle $50 \%$. Tarkastel- 
tavista syötteistä ainoastaan elintarviketeollisuuden sivutuotteet hygienisoitiin $\left(70{ }^{\circ} \mathrm{C}, 1 \mathrm{~h}\right)$ biokaasulaitoksella ennen prosessia. Ravinnepitoisuuksien ei oletettu muuttuvan hygienisoinnin aikana.

Biokaasulaitoksen tuottama energiamäärä laskettiin syötemateriaalien metaanintuottopotentiaalin ja orgaanisen aineen (VS) pitoisuuden avulla huomioiden energiantuotannon hyötysuhteet CHP:ssa (sähköntuotannon hyötysuhde $35 \%$, lämmöntuotannon hyötysuhde $50 \%$ ). Biokaasuketjuissa syötteistä biokaasuksi muuttuva massamäärä laskettiin metaanin ja hiilidioksidin tiheyden sekä oletetun biokaasun koostumuksen avulla $\left(60 \% \mathrm{CH}_{4}, 40 \% \mathrm{CO}_{2}\right)$. Käsittelyjäännöksen massa laskettiin syötteiden kokonaismäärän ja biokaasuun menevän massan määrän erotuksena. Biokaasuprosessin lämpöenergian tarve arvioitiin syötteen lämmittämiseen kuluvan energian ja reaktorin lämpöhäviöiden avulla (ks. Marttinen ym. 2015). Hygienisoinnin sähkönkulutukseksi oletettiin $0,085 \mathrm{kWh} / \mathrm{t}$ käsiteltävää materiaalia ja biokaasulaitoksen sähkönkulutuksen oletettiin olevan $3 \%$ laitoksen tuottamasta energiasta (asiantuntija-arvio, Pöschl ym. 2010).

Taulukko 2. Syötteiden ominaisuudet tuorepainossa.

\begin{tabular}{|l|l|l|l|l|l|l|l|l|}
\hline & $\begin{array}{l}\mathrm{TS} \\
(\%)\end{array}$ & $\begin{array}{l}\mathrm{VS} \\
(\%)\end{array}$ & $\begin{array}{l}\mathrm{N}_{\mathrm{kok}} \\
(\mathrm{g} / \mathrm{kg})\end{array}$ & $\begin{array}{l}\mathrm{NH}_{4}-\mathrm{N} \\
(\mathrm{g} / \mathrm{kg})\end{array}$ & $\begin{array}{l}\mathrm{P}_{\mathrm{kok}} \\
(\mathrm{g} / \mathrm{kg})\end{array}$ & $\begin{array}{l}\mathrm{K}_{\mathrm{kok}} \\
(\mathrm{g} / \mathrm{kg})\end{array}$ & $\begin{array}{l}\mathrm{CH}_{4} \text { tuotto } \\
\left(\mathrm{m}^{3} / \mathrm{tVS}\right)\end{array}$ & Lähteet \\
\hline Sian lietelanta (referenssiketju) & 6 & 4,7 & 4,0 & 2,6 & 1,2 & 2 & 320 & 1 \\
\hline Sian lietelanta (biokaasuketju) & 7,0 & 5,6 & 4,7 & 3,1 & 1,2 & 2,1 & 320 & 1 \\
\hline Sian lietelannan kuivajae & 27,9 & 22,6 & 8,3 & 3,5 & 5,5 & 1,5 & 300 & 1,2 \\
\hline HVP-nurmi & 37 & 34 & 11,8 & 1 & 0,9 & 6 & 270 & 4,6 \\
\hline Elintarviketeollisuuden sivuvirta & 20 & 16 & 8 & 4 & 1 & 1 & 300 & $3,4,5$ \\
\hline
\end{tabular}

${ }^{1}$ Hamelin ym. 2013, ${ }^{2}$ Laskennallinen, ${ }^{3}$ Kahiluoto \& Kuisma 2010, ${ }^{4}$ Luostarinen ym. 2011, ${ }^{5}$ Rasi ym. 2012,

${ }^{6}$ Niemeläinen ym. 2014

Kuljetusten osalta käytetyt lähtöarvot sekä lannan ja jäännöksen pumppaukseen ja sekoitukseen tarvittava kalusto, kapasiteetti ja polttoaineenkulutus on esitetty tarkemmin julkaisussa Marttinen ym. 2015. Biokaasulaitoksen ja tilan välisen kuljetuksen osalta oletuksena oli, että paluukuljetus sisältää käsittelyjäännöksen kuljetuksen takaisin tilalle. Lietelannalle biokaasulaitoksen ja tilan väliseksi etäisyydeksi oletettiin $10 \mathrm{~km}$, kun taas kuivalannan (BK1) osalta kuljetusetäisyys oletettiin pidemmäksi, $20 \mathrm{~km}$, johtuen kuivalannan paremmasta kuljetettavuudesta. Tilalta pellolle tapahtuvan kuljetuksen etäisyys oli kaikissa tarkastelluissa tilanteissa $5 \mathrm{~km}$, jolloin lietesäiliö ajetaan levityksen jälkeen tyhjänä takai$\sin$.

Ilmastovaikutukseen sisällytetyt päästöt olivat hiilidioksidi $\left(\mathrm{CO}_{2}\right)$, metaani $\left(\mathrm{CH}_{4}\right)$ ja dityppioksidi $\left(\mathrm{N}_{2} \mathrm{O}\right)$, joiden päästöt yhteismitallistettiin hiilidioksidiekvivalenteiksi $\left(\mathrm{CO}_{2}\right.$-ekv) RES-direktiivin karakterisointikertoimien mukaan, jotka ovat:

$$
\begin{array}{ll}
\text { - } & \mathrm{CO}_{2}=1 \\
\text { - } & \mathrm{CH}_{4}=23 \\
\text { - } & \mathrm{N}_{2} \mathrm{O}=296
\end{array}
$$

Lietelannan varastoinnin ja peltokäytön ilmapäästöt perustuvat Grönroosin ym. (2009) kansalliseen ammoniakkipäästöinventaarioon, lukuun ottamatta varastoinnin metaanipäästöä, joka perustuu kansalliseen kasvihuonekaasuinventaarioon (Statistics Finland 2013). Käsittelyjäännöksen ja siitä separoitujen kuiva- ja nestejakeiden varastoinnin ja peltokäytön dityppioksidipäästöt laskettiin käyttämällä lietelannan, kuivalannan ja virtsan kertoimia, jotka on esitetty Grönroosin ym. (2009) julkaisussa. Käsittelyjäännökselle jakeineen ei laskettu metaanipäästöjä varastoinnista, sillä metaanipäästöjen oletettiin olevan hyvin alhaiset biokaasuprosessin jälkeen.

Lannan sekä käsittelyjäännöksen lastauksen ja levityksen päästöt laskettiin polttoaineen kulutuksen perusteella fossiilisen dieselin päästökertoimien mukaan. Kuljetusten päästökertoimet perustuvat VTT:n LIPASTO -tietokantaan. Myös itse biokaasulaitokselle laskettiin päästöjä CHP-tuotannosta perustuen tanskalaisiin mittaustuloksiin biokaasu-CHP-laitokselta (Kristenssen ym. ei vuosilukua).

Biokaasulaitoksessa syntyvän nettoenergian oletettiin korvaavan fossiilisilla polttoaineilla tuotettua energiaa, jolloin biokaasuketjulle laskettiin päästöhyvityksiä. Sähkön korvaushyöty laskettiin käyttämällä kivihiilen ominaispäästökerrointa, sillä markkinoille tuleva uusi sähkö korvaa marginaalienergiaa, jonka tässä tapauksessa oletettiin olevan kivihiiltä. Myös lämpöenergian oletettiin korvaavan fossiilisia polttoaineita, jolloin sekin tuo päästöhyvityksiä. Päästöhyvityksiä syntyy myös käsittelyjäännöksen ja sen eri jakeiden lannoitekäytöstä, joka korvaa mineraalilannoitteiden käyttöä. Korva- 
ushyödyn laskemiseen käytettiin Suomen keskimääräisen lannoitteen valmistuksen päästökerrointa 3,6 $\mathrm{kg} \mathrm{CO}_{2}$-ekv./kg N (Yara 2014).

\section{Tulokset ja tulosten tarkastelu}

Massa- ja ravinnetaseiden perusteella lisäsyötteen vaikutus biokaasuprosessin käsittelyjäännöksen määrään ja ominaisuuksiin oli tarkastelluissa ketjuissa vähäinen, koska lietelannan osuus syötteestä oli suuri, noin $80 \%$. Kaikissa biokaasuketjuissa syötteen massasta noin 5-6\% muodosti biokaasua lopun päätyessä käsittelyjäännökseen ja separoinnissa edelleen nestejakeeseen (78 \%) ja kuivajakeeseen (16 \%) (kuva 2). Koska käsittelyjäännös sisältää kaikki syötteen ravinteet, siirtyi separoinnissa kuivajakeeseen noin $30 \%$ kokonaistypestä, yli $70 \%$ kokonaisfosforista ja noin $10 \%$ kaliumista, loppujen päätyessä nestejakeeseen. Ammoniumtypen määrä lisääntyi biokaasuprosessissa orgaanisen typen liukoistumisen seurauksena n. $32 \%$.
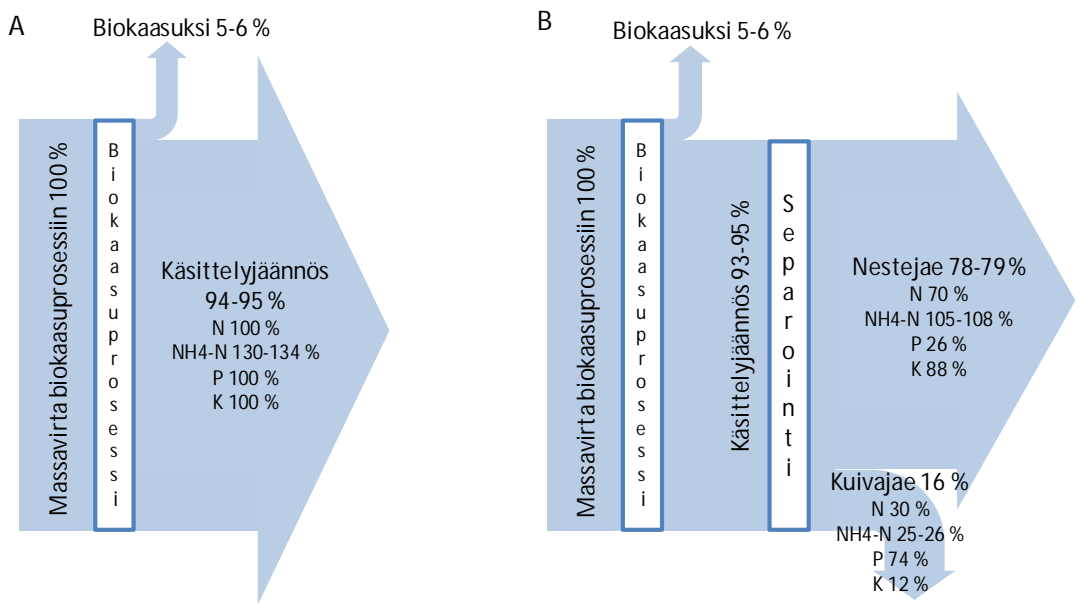

Kuva 2. Massavirran ja ravinteiden jakautuminen biokaasuketjuissa 1-3. A) Pelkkä biokaasuprosessi. B) Biokaasuprosessi ja separointi.

Biokaasulaitoksen energiantuottopotentiaali riippuu syötteiden ominaisuuksista, minkä vuoksi tuotetun biokaasun laskennallinen energiasisältö biokaasuketjuissa vaihteli välillä 4 600-6 $100 \mathrm{MWh} / \mathrm{a}$ (taulukko 3). Biokaasuketjuissa tuotettavissa olevat energiamäärät CHP:ssä olivat 1 600-2 $100 \mathrm{MWh} / \mathrm{a}$ sähkönä ja 2 300-3 $000 \mathrm{MWh/a} \mathrm{lämpönä.} \mathrm{CHP:n} \mathrm{tuottamasta} \mathrm{sähköstä} \mathrm{biokaasulaitoksen} \mathrm{toimintaan}$ kului noin $9 \%$ ja lämmöstä 22-31\%. Sähköä kului mm. pumppujen ja sekoittimien käyttöön ja lämpöä syötteiden lämmitykseen ja reaktorin lämpöhäviöiden kattamiseen. Syötteen orgaanisen aineen pitoisuus kuitenkin vaikuttaa suhteelliseen lämmönkulutukseen. Karkeasti voidaan todeta, että mitä pienempi orgaanisen aineen pitoisuus on syötteessä, sitä pienempi on syötteen energiasisältö ja sitä suurempi osuus tuotetusta lämmöstä kuluu syötteiden lämmittämiseen. Hygienisointi lisää prosessin lämmönkulutusta, mutta käytännössä hygienisoidusta materiaalista vapautuva lämpö voidaan hyödyntää laitoksella esim. lämmönvaihdintekniikan avulla. Käsittelyjäännöksen separointi kulutti ainoastaan 2-3\% tuotetusta sähköstä.

Kaikki ketjut tuottivat sähköä ja lämpöä yli oman tarpeen. Eniten hyödynnettävää ylijäämäenergiaa tuotti tarkastelluista tapauksista lantaa ja HVP-nurmea käsittelevä biokaasulaitos, jossa CHP:ssä tuotetusta sähköstä jäi laitoksen oman kulutuksen jälkeen hyödynnettäväksi $90 \%$ (1 $900 \mathrm{MWh}$ ) ja lämmöstä 77 \% (2 $300 \mathrm{MWh).} \mathrm{Tarkasteltaessa} \mathrm{koko} \mathrm{ketjuja} \mathrm{kuljetukset} \mathrm{ja} \mathrm{käsittelyjäännöksen} \mathrm{peltole-}$ vitys mukaan lukien, oli ketjujen kokonaisenergiankulutus 23-35 \% biokaasun energiasisällöstä. Energiankulutusten osalta on syytä huomioida, että biokaasulaitoksen toimintaa lukuun ottamatta valtaosa syötteiden hankintaan ja kuljetuksiin sekä käsittelyjäännöksen kuljetuksiin ja peltolevitykseen liittyvistä energiankulutuksista toteutuisi myös referenssiketjussa, joka ei sisällä biokaasulaitosta. 
Taulukko 3. Biokaasulaitosten energiantuotanto sekä kulutus.

\begin{tabular}{llll}
\hline MWh/a & $\begin{array}{l}\text { BK1, Sian lietelanta } \\
\text { + kuivajae }\end{array}$ & $\begin{array}{l}\text { BK2, Sian lietelanta } \\
\text { + HVP-nurmi }\end{array}$ & $\begin{array}{l}\text { BK3, Sian lietelanta + elintar- } \\
\text { viketeollisuuden sivuvirta }\end{array}$ \\
\hline Tuotettu energia & & & \\
\hline $\begin{array}{l}\text { Syötteiden energiasisältö } \\
\text { Sähkön tuotanto CHP:ssa }\end{array}$ & 5300 & 6100 & 4600 \\
Lämmön tuotanto CHP:ssa & 1800 & 2100 & 1600 \\
Kulutus & 2600 & 3000 & 2300 \\
\hline Biokaasuprosessi, sähkö & 160 & 180 & 140 \\
Biokaasuprosessi, lämpö & 680 & 680 & 710 \\
Separointi, sähkö & 40 & 40 & 40 \\
Lastaus, kuljetus, peltolevitys & 1000 & 560 & 540 \\
\hline
\end{tabular}

Biokaasuketjujen ilmastovaikutusta verrattiin referenssiketjuihin vuositasolla. Kaikkien tarkasteltujen biokaasuketjujen ilmastovaikutukset olivat huomattavasti alhaisemmat kuin vastaavan referenssiketjun (kuva 3). Biokaasuketjujen ilmastovaikutukset olivat negatiiviset, eli ketjussa syntyvät päästöt olivat pienemmät kuin korvattavien tuotteiden (mineraalilannoitteet ja fossiilinen energia) päästöt.

Pienin ilmastovaikutus oli biokaasuketjulla, joka käytti raaka-aineena sian lietelantaa ja HVPnurmea (kuva 3). Tämä johtuu siitä, että laitos tuotti eniten energiaa, jolloin korvaushyöty vältetystä fossiilisesta energiasta on suurin. Myös suurin ilmastovaikutuksen vähentyminen verrattuna referenssiketjuun saavutettiin lietelantaa ja HVP-nurmea käyttävällä laitoksella, mutta ilmastovaikutuksen vähentyminen oli lähes yhtä suuri lietelantaa ja lannan kuivajaetta käyttävällä laitoksella, vaikka tämän vaihtoehdon päästöjen vähentyminen on pienempi. Hyvä vertailutulos johtuu referenssiketjun korkeista päästöistä.

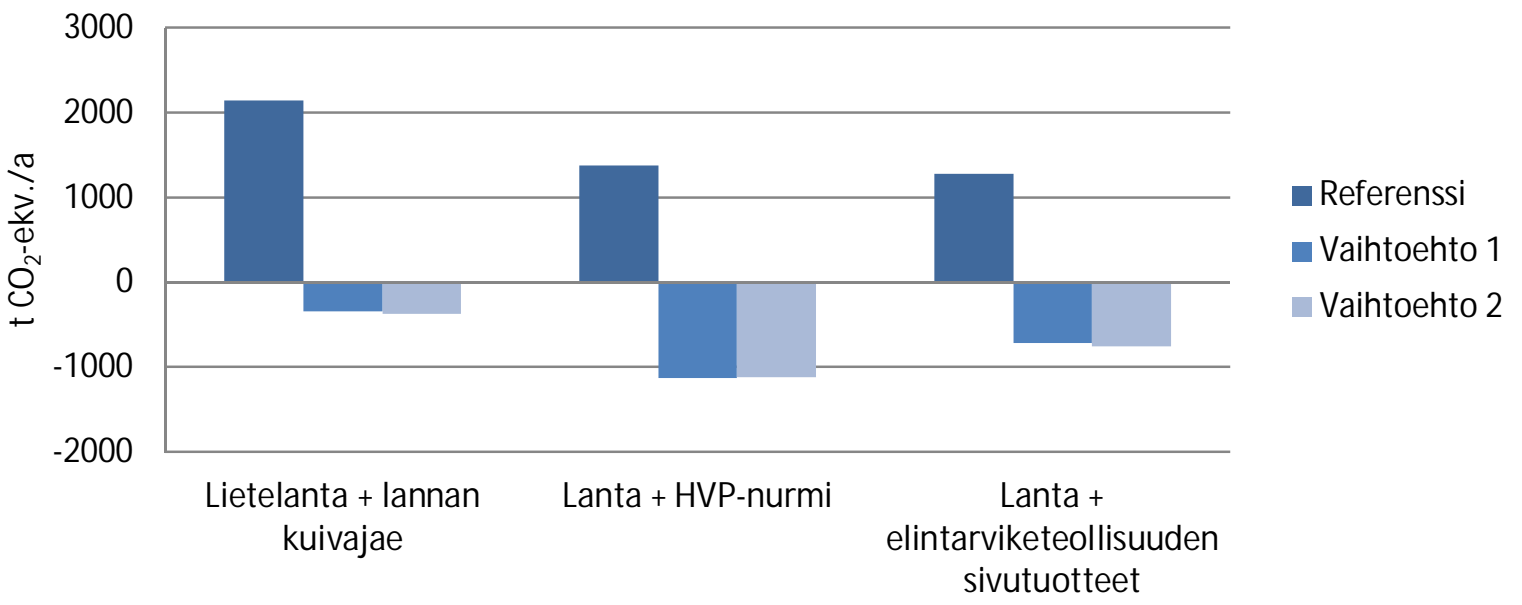

Kuva 3. Biokaasuketjujen ilmastovaikutukset verrattuna referenssiketjuihin ( $\mathrm{C}_{2}$-ekv./vuodessa). Vaihtoehdossa 1 käsittelyjäännös hyödynnetään sellaisenaan ja vaihtoehdossa 2 se separoidaan ennen lannoitekäyttöä. Pelkkää lantaa käsittelevässä ketjussa päästöjä lisää suurempi lantamäärä (36 792 t) kuin kahdessa muussa ketjussa $(16000 \mathrm{t})$.

Suurin ilmastovaikutus biokaasuketjuissa aiheutuu jäännöksen peltokäytöstä. Ilmastonmuutoksen kannalta ei ole merkittävää eroa käytetäänkö jäännös pellolla sellaisenaan vai separoituna, sillä separointiin kuluva energiamäärä on pieni. Myöskään separoinnin vaikutus jäännöksen ravinnepitoisuuksiin ei vaikuta näihin päästöihin, sillä nykyiset laskentamallit laskevat päästöt kokonaistypestä, joka on molemmissa vaihtoehdoissa sama.

Tässä työssä käytettiin RES-direktiivin mukaista allokointia, jolloin kaikki biokaasuketjun päästöt allokoitiin biokaasulle. Ilmastovaikutuksia voidaan kuitenkin myös jakaa ketjussa syntyville päätuotteille, eli energialle ja lannoitevalmisteille (käsittelyjäännös) erilaisten allokointitapojen kuten taloudellisella ja massa-allokoinnilla. Taloudellisen allokoinnin tapauksessa yli puolet biokaasuketjun päästöistä voidaan allokoida syntyville ravinteille, jolloin tuotetun energian päästöt jäävät huomattavasti alhaisemmaksi kuin ilman allokointia (Marttinen ym. 2015). Massa-allokoinnin tapauksessa lähes kaikki päästöt (95\%) voidaan allokoida jäännökselle. Tästä huolimatta jäännöksen "valmistuksen" päästöt ovat alhaisemmat kuin mineraalilannoitteiden valmistuksen päästöt. Tämä vertailu ei ota huomioon valmistuksen jälkeen syntyviä päästöjä, joissa voi olla suuriakin eroja. 


\section{Johtopäätökset}

Pääasiassa lantaa käsittelevien, kapasiteetiltaan 19500 t/a laitosten lisäsyötteillä oli vain pieni vaikutus käsittelyjäännöksen ominaisuuksiin, kun lisäsyötteen määrä oli alle $20 \%$ kokonaismäärästä. Separoinnissa pääosa (74 \%) fosforista päätyi kuivajakeeseen, kun taas nestejae sisälsi 70 \% syötemateriaalin typestä ja $90 \%$ kaliumista. Lietelannan oma energiantuotto tuorepainoa kohti on pieni johtuen vesipitoisuudesta. Lisäsyötteinä käytetyt lietelannan kuivajae, HVP-nurmi, ja elintarviketeollisuuden sivutuotteet tuottivat 37-53\% biokaasulaitoksella muodostuvasta metaanin kokonaismäärästä, vaikka niiden osuus oli vain alle $20 \%$ syötteiden kokonaismassasta. HVP-nurmen energiantuotto oli hieman suurempi kuin muiden lisäsyötteiden. Ketjuissa, joissa lannan lisäsyötteenä oli HVP-nurmi tai elintarviketeollisuuden sivutuotteet, koko ketjun energiankulutus oli 30-35\% tuotetun biokaasun energiasisällöstä, jolloin ylijäämäenergiaa jäi 70-77 \%. Suurimmat energiankuluttajat olivat itse biokaasuprosessi (mm. laitteiden sähkönkulutus ja syötteiden lämmitys) sekä käsittelyjäännöksen levitys peltoon.

Verrattaessa biokaasuketjujen ilmastovaikutusta referenssiketjuihin oli kaikkien tarkasteltujen biokaasuketjujen ilmastovaikutukset huomattavasti pienemmät. Biokaasuketjujen ilmastovaikutukset olivat jopa negatiiviset eli biokaasuketjussa syntyvät päästöt kokonaisuudessaan olivat pienemmät kuin biokaasutuotannolla korvattavien tuotteiden eli mineraalilannoitteiden ja fossiilisen energian päästöt. Pienin ilmastovaikutus oli biokaasuketjulla, joka käytti raaka-aineena sian lietelantaa ja HVP -nurmea. Myös suurin ilmastovaikutuksen vähentyminen verrattuna referenssiketjuun saavutettiin lietelantaa ja HVP -nurmea käyttävällä laitoksella ja lähes yhtä suuri vähennys oli lietelantaa ja lannan kuivajaetta käyttävällä laitoksella. Suurin ilmastovaikutus biokaasuketjuissa aiheutuu jäännöksen peltokäytöstä.

\section{Kirjallisuus}

Grönroos, J., Mattila, P., Regina, K., Nousiainen, J., Perälä, P., Saarinen, K. \& Mikkola-Pusa, J. 2009. Development of the ammonia emission inventory in Finland. Revised model for agriculture. The Finnish Environment 8/2009. http://hdl.handle.net/10138/38030

Hamelin, L., Baky, A., Cano-Bernal, Grönroos, J., Kuligowski, K., Pehme, S., Rankinen, K., Skura, D., Wenzel, H., Wesnæs, M. \& Ziolkowsky, M. 2013. Reference life cycle assessment scenarios for manure management in the Balti Sea regions. Knowledge report. Baltic Manure WP5 Assessing Sustainability of Manure Technology Chains. December 2013.

http://www.balticmanure.eu/download/Reports/lcareference_report_wp5_web.pdf

Hjorth, M., Christensen, K.V., Christensen, M.L. \& Sommer, S.G. 2010. Solid-liquid separation of animal slurry in theory and practice. A review. Agron. Sustain. Dev. 30, 153-180.

Kahiluoto, H. \& Kuisma, M. 2010. Elintarvikeketjun jätteet ja sivuvirrat energiaksi ja lannoitteiksi. JaloJätetutkimushankkeen synteesiraportti. MTT Kasvu 12. http://www.mtt.fi/mttkasvu/pdf/mttkasvu12b.pdf

Kristensen, P.G., Jensen, J.K., Nielsen, M. \& Illerup, J.B. Emission factors for gas fired CHP units < 25 MW. Saatavissa:

http://www.neri.dk/1_viden/2_Miljoetilstand/3_luft/4_adaei/doc/EmissionfactorsforgasfiredCHPunits.pdf

Luostarinen, S., Logrén J., Grönroos, J., Lehtonen, H., Paavola, T., Rankinen, K., Rintala, J., Salo, T., Ylivainio, K. \& Järvenpää, M. 2011. Lannan kestävä hyödyntäminen. HYÖTYLANTA-tutkimusohjelman loppuraportti. MTT Raportti 21. http://www.mtt.fi/mttraportti/pdf/mttraportti21.pdf

Marttinen, S., Tampio, E., Sinkko, T., Timonen, K., Luostarinen, S., Grönroos, J. \& Manninen, K. 2015. Biokaasulaitokset - syötteistä lopputuotteisiin. Energia, ravinteet ja ympäristövaikutukset. Luonnonvara- ja biotalouden tutkimus 14/2015. http://urn.fi/URN:ISBN:978-952-326-013-9

Møller, H.B., Lund, I. \& Sommer, S.G. 2009. Solid-liquid separation of livestock slurry: efficiency and cost. Bioresour. Technol. 74, 223-229.

Niemeläinen, O., Hyvönen, T., Jauhiainen, L., Lötjönen, T., Virkkunen, E. \& Uusi-Kämppä, J. 2014. Hoidettu viljelemätön pelto biokaasuksi - biomassan sopivuus syötteeksi ja korjuun vaikutukset tutkimusohjelmien muiden tavoitteiden saavuttamiseen. Loppuraportti.

Pöschl, M., Ward, S. \& Owende, P. 2010. Evaluation of energy efficiency of various biogas production and utilization pathways. Appl. Energ. 87, 3305-3321.

Rasi, S., Lehtonen, E., Aro-Heinilä, E., Höhn, J., Ojanen, H., Havukainen, J., Uusitalo, V., Manninen, K., Heino, E., Teerioja, N., Anderson, R., Pyykkönen, V., Ahonen, S., Marttinen, S., Pitkänen, S., Hellstedt, M. \& Rintala, J. 2012. From Waste to Traffic Fuel -projects. Final report. MTT Report 50. http://www.mtt.fi/mttraportti/pdf/mttraportti50.pdf

Statistics Finland. 2013. Greenhouse gas emissions in Finland 1990-2011. Draft. National Inventory Report under the UNFCCC and the Kyoto Protocol. Submission to the European Union. 15 January 2013.

Yara. 2014. Hiilijalanjälkitakuu. Saatavissa: http://www.yara.fi/tietoa-yarasta/kestava-kehitys/hiilijalanjalki/ 